\title{
Growth Performance and Sexual Maturity in Malaysian Kedah- Kelantan and Kedah-Kelantan $\times$ Brangus Bulls
}

\section{Mohammed Sirajul Islam ${ }^{1,2 *}$, Nurhusien Yimer $^{1 *}$, Wahid Haron ${ }^{1}$, Faez Firdaus Abdullah Jesse $^{1}$, Mark Hiew Wen Han ${ }^{1}$, Mamat-Hamidi Kamalludin ${ }^{3}$, Wan-Nor Fitri ${ }^{1}$, Ubedullah $\mathrm{KaKA}^{4}$, ABdul Quddus ${ }^{1,5}$}

${ }^{1}$ Department of Veterinary Clinical Studies, Faculty of Veterinary Medicine, Universiti Putra Malaysia, 43400 Serdang, Selangor, Malaysia; ${ }^{2}$ Bangladesh Livestock Research Institute, Savar, Dhaka-1341, Bangladesh; ${ }^{3}$ Department of Animal Science, Faculty of Agriculture, Universiti Putra Malaysia, 43400 Serdang, Selangor, Malaysia; ${ }^{4}$ Department of Companion Animal Medicine and Surgery, Universiti Putra Malaysia, 43400 Serdang, Selangor, Malaysia; ${ }^{5}$ Department of Water and Marine Sciences, Lasbela University of Agriculture, Uthal, Balochistan, Pakistan.

\begin{abstract}
Domestic beef production in Malaysia is mainly contributed by the indigenous Kedah-Kelantan (KK) and their crossbred cattle. This study was conducted to compare growth performance and sexual maturity of KK and KK $\times$ Brangus bulls. Ten (10) experimental bulls with similar ages were kept under the same paddock and fed with equal quality and quantity Guinea grasses and palm kernel cakes. Body weight was measured at monthly basis by using a digital animal weighing scale. Age at sexual maturity was determined by the time of semen ejaculation and quality. The results revealed significantly $(\mathrm{p}<0.05)$ greater body weight in $\mathrm{KK} \times$ Brangus bulls $(230.50 \pm 9.3 \mathrm{~kg})$ as compared to the pure-bred KK bulls $(204.5 \pm 13.2 \mathrm{~kg})$ at 24 months of ages. KK bulls attained sexual maturity at an earlier age of $21.5 \pm 0.4$ months, while $\mathrm{KK} \times$ Brangus bulls attained at $28.8 \pm 0.5$ months. The growth performance of KK $\times$ Brangus bulls was significantly $(\mathrm{p}<0.05)$ higher than KK bulls. Age showed a significant positive correlation with body weight and average daily weight gains. In conclusion, KK pure-bred bulls were superior in terms of attaining age at puberty and sexual maturity earlier, whereas $\mathrm{KK} \times$ Brangus bulls were better for growth performance.
\end{abstract}

Keywords | Kedah-Kelantan bull, Age, Average daily gain, Body weight, Sexual maturity

Received | May 25, 2021; Accepted | July 25, 2021; Published | January 10, 2022

*Correspondence | Nurhusien Yimer and Mohammed Sirajul Islam, Department of Veterinary Clinical Studies, Faculty of Veterinary Medicine, Universiti Putra Malaysia, 43400 Serdang, Selangor, Malaysia; Email: nurhusien@upm.edu.my, siraj_blri@yahoo.com

Citation | Islam MS, Yimer N, Islam MS, Yimer N, Wahid H, Jesse FFA, Hiew MWH, Kamalludin M, Fitri WN, Kaka U, Quddus A (2022). Growth performance and sexual maturity in Malaysian Kedah-Kelantan and Kedah-Kelantan $\times$ Brangus bulls. Adv. Anim. Vet. Sci. 10(2): 397-404.

DOI | http://dx.doi.org/10.17582/journal.aavs/2022/10.2.397.404

ISSN (Online) | 2307-8316

\section{INTRODUCTION}

K edah-Kelantan (KK) is a (Bos indicus) locally adapted beef cattle in Malaysia. KK cattle contribute an important role for the sustainable beef production in Malaysia since the imported exotic breeds, crossbreds and synthetic breeds of cattle could not perform at their full potential (Islam et al., 2021). Survivability to harsh environment, adaptability to climatic changes, sustainability to low quality feeds and houses, rusticity to traditional farming system, fertility to produce a calf per year are the important features of Malaysian KK breed (Clayton, 1983; Hafiz et al., 2009; Ariff et al., 2015; Mastura et al., 2019; Islam et al., 2021). Consequently, the importance of KK cattle has been increasing gradually in consideration to the changing climatic situation and adaptibility. There were about 425,298 (62.22\%) KK purebred, 225,377 (32.98\%) crossbred and 32826 (4.8\%) dairy cattle, respectively out of total cattle population of 683,501 heads in Malaysia (Department of Veterinary Services, 2020). Malaysian domestic beef production fully depends on indigenous KK and KK crossbred cattle contributing approximately 
$20 \%$ of the total demand of beef requirement (Jamaludin et al., 2014). There were different crossbreds, which composed of $50 \% \mathrm{KK}$ cows with $50 \%$ exotic breeds like Brahman, Charolais, Hereford and Brangus (Ariff et al., 2015). Growth performance of KK crossbred cattle showed to be better than KK, on the other hand, crossbred showed comparatively lower reproductive performances (Jamaludin et al., 2014). However, KK cows have been crossed with different exotic breeds in order to increase the productivity traits especially growth rate taking the advantage of heterosis by combining the desirable traits of two or more breeds (Johari and Jasmi, 2009). However, the profitability and sustainability of KK crossbred cattle have been declined due to their poor reproductive performance and survivabilty within this tropical environment (Jamaludin et al., 2014).

Body weight gain is the most essential tool to assess the reproductive efficiency and growth performance of breeding animals. It is also a good indicator to avoid overfeeding or underfeeding of breeding bulls by determine the correct amount of feed. Bodyweight measurement in young bulls is the initially simple and easy technique to select bulls as sire for breeding purposes. Moreover, body weight helps to determine age of puberty of male and female animals. Growth is defined as a progressive increase in size or weight of an animal in a specific timeframe (Bureš and Barton, 2012). Growth performance in the peri-pubertal age is a good indicator of reproductive efficiency of bulls for artificial insemination program or natural services. Growth of an animal is a multifactorial issue directly related to breed type, age and their environment (Lee et al., 2009; Silva et al., 2017). On the other hand, growth affects greatly the semen quality especially sperm motility, sperm concentration and sperm morphology of breeding bulls. So, it is necessary to know the growth performance of $\mathrm{KK}$ bulls compared to their crossbreds to select a suitable sire animal for efficient $\mathrm{KK}$ production.

Productivity of beef cattle is mainly affected by genetic potential, their environmental factors, and interactions of their genetic and environment (Sodiq et al., 2019). The contribution of genetic potential is about $30 \%$ while remaining $70 \%$ comes from their environmental factors and interactions of both factors can be minimise by supporting appropriate environment (Gamborg and Sandoe, 2005). Breed type is one of the most important factor that influencing the productivity of beef. Purebred $\mathrm{KK}$ and their crossbred are the major pillars of beef production in Malaysia. There is scarcity of literature on the comparative studies between $\mathrm{KK}$ and $\mathrm{KK} \times$ Brangus bulls for their growth performance and sexual maturity and relationship of age with growth performance. Therefore, this study was aimed to determine the existing potentiality of growth performance and sexual maturity in KK bulls by comparing with $\mathrm{KK} \times$ Brangus bulls.

\section{MATERIALS AND METHODS}

\section{ANIMAL WELFARE AND ETHICAL APPROVAL}

This study was approved by the Institutional Animal Care and Use Committee (IACUC), Universiti Putra Malaysia, Malaysia (UPM/IACUC/AUP-R096/2018). The care of the experimental animals were strictly followed by the UPM animal welfare and ethics policies and guidelines.

\section{SELECTION OF EXPERIMENTAL ANIMALS}

KK pure-bred bulls were selected from Pusat Ternakan Haiwan Pantai Timur, Department of Veterinary Services (DVS), Tanah Merah Kelantan, Malaysia where a breeding herd of purebred $\mathrm{KK}$ having population more than 500 heads were maintained. Six KK bulls nearly the same ages were selected after visual observation of their general, physical and morphological structured along with phenotypic characteristics. Four $\mathrm{KK} \times$ Brangus bulls of about similar ages were selected from the beef cattle unit of Taman Pertanian Universiti (PTU), UPM, Malaysia followed by the same procedure.

\section{LOCATION AND DURATION OF EXPERIMENT}

The experiment was conducted at beef cattle unit, Ladang 16, Taman Pertanian University (TPU), UPM, Serdang, Selangor, Malaysia (259'09" N; 101 43'51" E) from 12 March 2019 to 30 September 2020. Annual range of Malaysian temperature, humidity and rainfall were $28^{\circ}$ to $30^{\circ} \mathrm{C}, 73$ to $80 \%$ and 86.70 to $313.00 \mathrm{~mm}$, respectively, during the experimental period.

\section{Management of experimental animals}

All experimental bulls were reared under the same paddock with equal feeding, watering and management facilities. Deworming program was performed at three-month interval to control parasitic diseases. Vaccination against Foot and Mouth Disease (FMD) and Haemorrhagic Septicaemia (HS) were given to all animals. Proper biosecurity measures were ensured regularly to prevent the outbreak of any diseases.

\section{FEEDING AND WATERING OF ANIMALS}

Guinea grasses (Megathraysus maximus) were provided to all animals together in the morning from 8 to 10 am daily through cut and carry system without measuring grass weight. Generally, Guinea grass is used for livestock feeding throughout the year at TPU. Nutritional composition of Guinea grasses and palm kernel cakes (PKC) were shown in Table 1. Palm kernel cake (PKC) @3kg /bull/day were given to all animals in the afternoon. All bulls had equal facility to take PKC at the same time on a long feeder trough. Salt-mineral blocks were put above feeder trough 
for licking by animals in any time of a day. Molasses were also mixed with drinking water daily. Sufficient fresh water was ensured in all time. Feed intake was not measured during study period.

Table 1: Nutritive Values of Guinea Grass (Panicum/ Megathraysus Maximus) and Palm Kernel Cake (PKC).

\begin{tabular}{lllll} 
Variables & \multicolumn{2}{c}{ Guinea grass } & \multicolumn{2}{c}{ PKC } \\
& Mean & SD & Mean & SD \\
Dry matter (DM) & 13.8 & 0.8 & 92.6 & 0.5 \\
Crude protein (CP) & 15.1 & 1.5 & 16.4 & 0.9 \\
Crude fiber (CF) & 40.1 & 1.1 & 19.7 & 0.6 \\
Ash/mineral & 1.1 & 0.1 & 4.9 & 0.3 \\
Ether Extract (EE) & 0.3 & 0.1 & 5.2 & 0.2 \\
ME $(\mathrm{MJ} / \mathrm{kg})$ & 10.1 & 0.7 & 10.7 & 0.4 \\
SD, standard deviation; PKC, palm kernel cake. &
\end{tabular}

\section{Measurement of GROWTH PERFormance}

Age of experimental bulls was calculated from the birth dates recorded at the breeding farm. Average birth weights of $\mathrm{KK}$ and $\mathrm{KK} \times$ Brangus bulls as recorded in the herd book were 16.67 and $29.00 \mathrm{~kg}$, respectively. Bodyweight was measured monthly by the Tru-Test-EC2000 animal weighing balance made in New Zealand (Auckland). Average monthly weight gains $(\mathrm{g} / \mathrm{d})$ in different age were calculated by dividing the initial and final body weight differences with the total number of days between two stages of live weights (Nazli et al., 2018). Puberty was defined when a bull produced an ejaculate containing a minimum of $50 \times 10^{6}$ sperm cells with minimum $10 \%$ motile (Wolf et al., 1965). At least one sample from each bull was collected monthly after first ejaculation to determine the age at puberty of bulls. Maturity was determined when an ejaculate contained $\geq 30 \%$ motile and $\geq 70 \%$ morphologically normal sperm (Barth, 2004; Brito et al., 2012). Then body weight and average monthly weight gain at puberty and maturity of $\mathrm{KK}$ and $\mathrm{KK} \times$ Brangus bulls were calculated accordingly.

\section{GROWTH PERFORMANCE IN WET AND DRY SEASON}

Climate of Malaysia is tropical due to its location, which is near equator with high temperature, humidity and rainfall throughout the year. It has mainly two seasons like wet season from April to October (7-month) and dry season from November to March (5-month). Body weight and average daily gain of $\mathrm{KK}$ and $\mathrm{KK} \times$ Brangus bulls were compared in both wet season from April 2019 to October 2019 and dry season from November 2019 to March 2020.

\section{STATISTICAL ANALYSIS}

Data were statistically analysed for calculating mean ( \pm SEM) and analysis of variance using independent sample t-test. Analysis was performed by international business machines (IBM) SPSS software of version 22 to determine the significance of differences between KK and $\mathrm{KK} \times$ Brangus bulls from 13 to 30 month of ages. Pearson correlation coefficient was determined between age, body weight and ADG of KK and its crosses with Brangus bulls using Bi-variate correlations. Differences at 0.05 were considered to be statistically significant. Prediction of the value of body weight and its relationship with age and average daily gain was assessed based on model summary $\left(\mathrm{R}\right.$ and $\mathrm{R}^{2}$ ) of the following regression or prediction equation:

$$
\hat{Y}=B o+B_{1} X_{1}+B_{2} X_{2}
$$

Where; $Y=D e p e n d e n t$ variable, $\hat{Y}=$ Predicted value of body weight $(\mathrm{Y}), \mathrm{Bo}=\mathrm{Y}$-intercept, $\mathrm{X}_{1}=$ age of bulls, $\mathrm{X}_{2}=$ average daily gain and $\mathrm{B}_{1-2}=$ regression coefficients

\section{RESULTS AND DISCUSSION}

\section{BODY WEIGHT}

Table 2 represents the body weight $(\mathrm{kg})$ of $\mathrm{KK}$ and $\mathrm{KK} \times$ Brangus bulls from 13 to 24 month of ages. Overall body weight trend of $\mathrm{KK} \times$ Brangus bulls were consistently heavier than KK bulls from 13 to 24 month except that at 18 month of age. No significant differences ( $>0.05$ ) of body weights were found from 13 to 17 months of age despite of greater body weight tendency in $\mathrm{KK} \times$ Brangus bulls than KK bulls. Surprisingly, mean body weight at 18-month was insignificantly $(\mathrm{p}>0.05)$ higher in KK $(147.4 \pm 12.6 \mathrm{~kg})$ as compared to KK $\times$ Brangus bulls $(146.5 \pm 1.2 \mathrm{~kg})$. Significant differences $(\mathrm{p}<0.05)$ of body weights were obtained in both genotypes from 21 to 24 months age. There were $181.9 \pm 14.3 \mathrm{~kg}$ and $198.0 \pm 5.2 \mathrm{~kg}$ of body weights for $\mathrm{KK}$ and $\mathrm{KK} \times \mathrm{Brangus}$ bulls, respectively, at 21 months of age. The mean body weights at 24 months of age were $204.5 \pm 13.2 \mathrm{~kg}$ and $230.5 \pm 9.3 \mathrm{~kg}$ for KK and $\mathrm{KK} \times$ Brangus bulls, respectively, with significance difference $(\mathrm{p}<0.05)$. The mean difference between KK and $\mathrm{KK} \times$ Brangus bulls were $16.1 \mathrm{~kg}$ at 21 months while it was $26.0 \mathrm{~kg}$ at 24 months of age which is almost double than 21 months of range.

Table 3 showed the comparison of age and body weight at puberty and maturity between $\mathrm{KK}$ and $\mathrm{KK} \times$ Brangus bulls. Mean differences for age (5.5-month) and body weight $(88.1 \mathrm{~kg})$ at puberty were significantly higher $\mathrm{p}<0.001)$ in $\mathrm{KK} \times$ Brangus bulls compared to KK purebred. Mean age at puberty was $18.0 \pm 0.4$ and $23.5 \pm 0.3$ months for KK and $\mathrm{KK} \times$ Brangus bulls, respectively. KK $\times$ Brangus bulls did not appear to reach their puberty before 23 months of age. KK bulls attained puberty in significantly $(\mathrm{p}<0.001)$ earlier age (7.3-month) than their counterparts, although, $\mathrm{KK} \times$ Brangus bulls were significantly $(p<0.01)$ heavier body 
weight $(49.8 \mathrm{~kg})$ at the age of maturity.

Table 2: Comparison monthly body weight $(\mathrm{kg})$ of $\mathrm{KK}$ and $\mathrm{KK} \times$ Brangus bulls.

\begin{tabular}{|c|c|c|c|c|c|c|}
\hline \multirow[t]{2}{*}{$\begin{array}{l}\text { Age } \\
\text { (month) }\end{array}$} & \multicolumn{2}{|c|}{ KK bulls } & \multicolumn{2}{|c|}{$\begin{array}{l}\text { KK } \times \text { Brangus } \\
\text { bulls }\end{array}$} & \multirow[t]{2}{*}{$P$-value } & \multirow{2}{*}{$\begin{array}{l}\text { Mean } \\
\text { differ- } \\
\text { ence }\end{array}$} \\
\hline & Mean & SEM & Mean & SEM & & \\
\hline 13 & 98.13 & 9.68 & 111.88 & 3.11 & $.162^{\mathrm{NS}}$ & 13.75 \\
\hline 14 & 105.63 & 10.30 & 116.25 & 4.13 & $.298^{\mathrm{NS}}$ & 10.62 \\
\hline 15 & 110.38 & 11.40 & 119.25 & 4.13 & $.357^{\mathrm{NS}}$ & 8.88 \\
\hline 16 & 117.25 & 11.72 & 124.50 & 3.63 & $.642^{\mathrm{NS}}$ & 7.25 \\
\hline 17 & 132.25 & 12.36 & 134.00 & 2.68 & $.794^{\mathrm{NS}}$ & 1.75 \\
\hline 18 & 147.38 & 12.58 & 146.50 & 1.19 & $.947^{\mathrm{NS}}$ & .875 \\
\hline 19 & 155.88 & 13.08 & 163.00 & 1.58 & $.508^{\mathrm{NS}}$ & 7.13 \\
\hline 20 & 165.88 & 14.44 & 174.75 & 3.82 & $.353^{\mathrm{NS}}$ & 8.88 \\
\hline 21 & 181.88 & 14.34 & 198.00 & 5.21 & $.045^{*}$ & 16.13 \\
\hline 22 & 195.38 & 14.55 & 217.00 & 8.01 & $.033^{*}$ & 21.63 \\
\hline 23 & 201.50 & 13.81 & 223.25 & 9.07 & $.028^{*}$ & 21.75 \\
\hline 24 & 204.50 & 13.22 & 230.50 & 9.32 & $.015^{*}$ & 26.00 \\
\hline
\end{tabular}

SEM, standard error of mean; *, significant $(p<0.05)$ and NS, Non-significant difference ( $\mathrm{p}>0.05)$.

Table 3: Comparison of age and body weight at puberty and maturity in $\mathrm{KK}$ and $\mathrm{KK} \times$ Brangus bulls

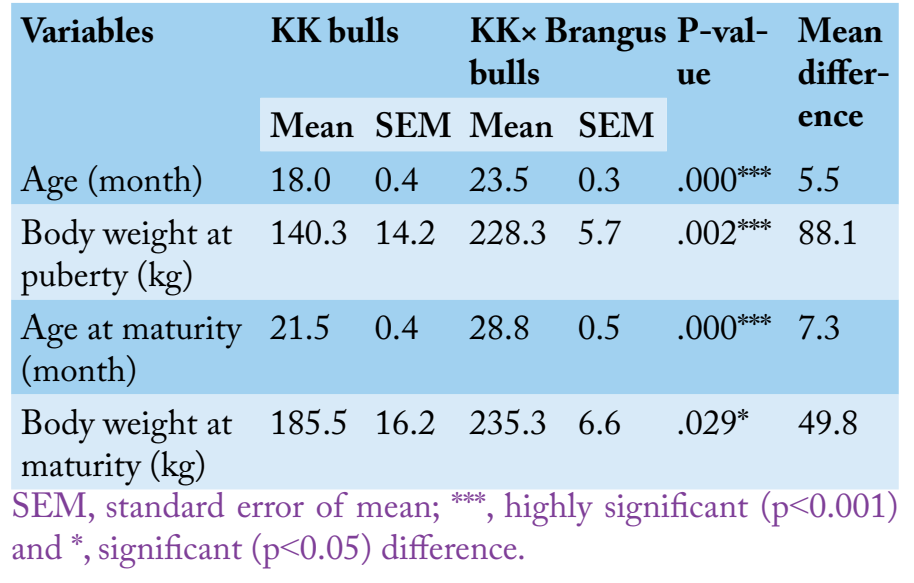

\section{AvERAGE DAILY WEIGHT GAIN}

The average monthly weight gains $(\mathrm{g} / \mathrm{d})$ of $\mathrm{KK}$ and $\mathrm{KK}$ $\times$ Brangus bulls from 13 to 24 months of age is plotted in Figure 1. The highest and the lowest average monthly weight gains $(\mathrm{g} / \mathrm{d})$ were displayed at 21 and 13 month of age, respectively, between KK and $\mathrm{KK} \times \mathrm{Brangus}$ bulls. The highest weight gains $(\mathrm{g} / \mathrm{d})$ was found at 21 months of age in both bulls with significant difference $(\mathrm{p}<0.05)$ between genotypes. The Figure 1 clearly showed the message that the monthly weight gain $(\mathrm{g} / \mathrm{d})$ of KK was better than KK $\times$ Brangus bulls upto 18 months, while after 18 months it seemed in favour of the later genotype. However, growth performance from 13 to 24 months of age revealed the inconsistency by fluctuating 3 times in both types of bulls. Although, monthly daily gains in $\mathrm{KK} \times$ Brangus bulls was highly fluctuated compare to KK bulls. Moreover, ADG in $\mathrm{KK} \times$ Brangus was gradually increased from 15 months until 19 months, then suddenly decreased at 20 month of age. Again it was surprisingly increased at 21 months, afterwards it was drastically decreased up to 23 months. Similarly, ADG in KK was consistently increased from 15 to18 months, then declined quickly at 19-month. Again, it was surprisingly increased until 21 months, then sharply reduced up to 23 months. Moreover, ADG was significantly $(p<0.05)$ different at 19 months of age between genotypes.

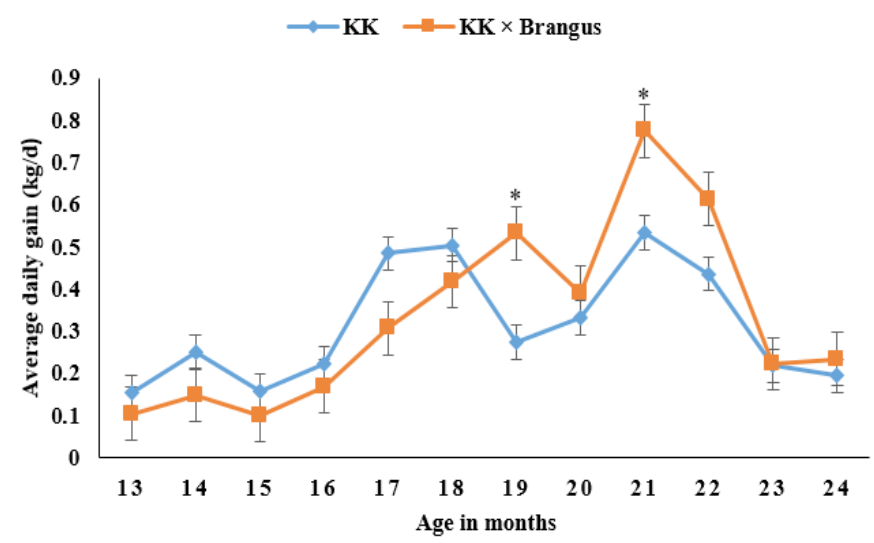

Figure 1: Average daily gain $(\mathrm{kg} / \mathrm{d})$ of $\mathrm{KK}$ and $\mathrm{KK} \times$ Brangus bulls from 13 to 24 months of age. *, significant $(\mathrm{p}<0.05)$ difference.

The ADG from 13 to 18 months, 19 to 24 month, 25 to 30 months and 13 to age at puberty and maturity delineated in Table 4. ADG from 13 to 18 -month was significantly $(p<0.05)$ higher in $\mathrm{KK}$, whereas, it was significantly $(\mathrm{p}<0.05)$ higher in $\mathrm{KK} \times$ Brangus bulls from 13 months to puberty. The ADG from 13 to 18 -months of age were $0.27 \pm 0.03$ and $0.19 \pm 0.02 \mathrm{~kg}$ for $\mathrm{KK}$ and $\mathrm{KK} \times$ Brangus bulls, respectively. On the other hand, ADG from 13 to age at puberty were $0.27 \pm 0.03$ and $0.35 \pm 0.02 \mathrm{~kg}$ for $\mathrm{KK}$ and $\mathrm{KK} \times$ Brangus bulls respectively. There were no significant differences of ADG from 19 to 24 -month, 25 to 30 -month and 13 to age at maturity between $\mathrm{KK}$ and $\mathrm{KK} \times$ Brangus bulls.

Table 4: ADG of KK and KK $\times$ Brangus bulls from 13 to 30 months of age.

\begin{tabular}{lllllll|}
$\begin{array}{l}\text { Age period } \\
\text { (month) }\end{array}$ & \multicolumn{4}{l}{ KK bulls } & \multicolumn{3}{l}{ KK $\times$ Brangus bulls. Sig. } \\
\hline 13 to 18 months & .27 & .03 & .19 & .02 & $.043^{*}$ \\
19 to 24 months & .29 & .02 & .36 & .05 & $.139^{\text {NS }}$ \\
25 to 30 months & -.13 & .02 & -.16 & .04 & $.204^{\text {NS }}$ \\
$\begin{array}{l}13 \text { to age at } \\
\text { puberty }\end{array}$ & .27 & .03 & .35 & .02 & $.048^{*}$ \\
$\begin{array}{l}13 \text { to age at } \\
\text { maturity }\end{array}$ & .37 & .04 & .29 & .02 & $.198^{\text {NS }}$ \\
\hline
\end{tabular}

SEM, standard error of mean; , significant $(\mathrm{p}<0.05)$ and NS, Non-significant $(\mathrm{p}>0.05)$. 
EFFECT OF SEASONS ON GROWTH PERFORMANCE

Effect of seasons on average daily gain $(\mathrm{kg} / \mathrm{d})$ in $\mathrm{KK}$ and $\mathrm{KK}$ $\times$ Brangus bulls during experimental period is presented in Table 5. ADG in KK bulls was $0.28 \pm 0.03$ and $0.20 \pm 0.14$ $\mathrm{kg} / \mathrm{d}$ for wet season and dry season, respectively, with no significant $(\mathrm{p}>0.05)$ differences. No significant difference $(p>0.05)$ between wet and dry season was obtained in KK $\times$ Brangus bulls.

Table 5: Effect of dry and wet season on average daily gain $(\mathrm{kg} / \mathrm{d})$ in $\mathrm{KK}$ and $\mathrm{KK} \times$ Brangus bulls.

\begin{tabular}{llllll} 
Breed type & \multicolumn{2}{l}{ Types of seasons } & \multicolumn{2}{c}{ Pvalue } \\
& $\begin{array}{l}\text { Wet (April } \\
\text { to October) }\end{array}$ & $\begin{array}{l}\text { Dry (November to } \\
\text { March) }\end{array}$ & \\
& Mean & SEM & Mean & SEM & \\
\hline KK bulls & 0.28 & 0.03 & 0.20 & 0.14 & $0.077^{\text {NS }}$ \\
KK $\times$ Brangus bulls & 0.24 & 0.02 & 0.27 & 0.04 & $0.630^{\text {NS }}$ \\
\hline
\end{tabular}

SEM, standard error of mean and NS, Non-significant $(\mathrm{p}>0.05)$.

The correlation coefficients of age with body weight and ADG were explained in Table 6. Age was positively, strongly and significantly $(\mathrm{p}<0.01)$ correlated with body weight in both $\mathrm{KK}(\mathrm{r}=0.99)$ and $\mathrm{KK} \times$ Brangus bulls $(\mathrm{r}$ $=0.98)$. Age was positively but non-significantly $(\mathrm{p}>0.05)$ correlated with ADG in both genotypes.

Table 6: Correlation coefficients between age, bodyweight and ADG in KK and $\mathrm{KK} \times$ Brangus bulls.

\begin{tabular}{lll} 
Parameters & \multicolumn{2}{c}{ Breed types } \\
\hline Age with body weight & $0.99^{* *}$ & $0.98^{* *}$ \\
Age with ADG & 0.26 & 0.52 \\
*** Correlation is significant at 0.01 level (two-tailed).
\end{tabular}

\section{Prediction of Body Weight PERFormance}

Multiple regression analysis for variables predicting the body weight performance of the experimental bulls are summarised in Table 7 . There was a high relationship $(\mathrm{R}=.995)$ between the two factors (age and $A D G)$ and body weight. Age and ADG together can be explained significantly $99.0 \%$ variance in body weight performance $\left(\mathrm{R}^{2}=.990\right)$. The regression model fits the data at .05 level of significance $(\mathrm{F}=.000)$. Age significantly $(\mathrm{p}=.000, \mathrm{t}=28.35)$ predicted the body weight performance while ADG did not contribute significantly ( $\mathrm{p}=.46, \mathrm{t}=.78$ ) to body weight performance.

In this study, the mean body weights were 98.1 and $111.9 \mathrm{~kg}$ for $\mathrm{KK}$ and $\mathrm{KK} \times$ Brangus bulls, respectively at 13 months with no significant difference ( $p>0.05$ ). This finding is in close agreement with the results of (Ariff et al., 1993; Islam et al., 2021) who reported the mean body weight in KK males as 102.3 and $100.5 \mathrm{~kg}$, respectively. Although, the results of this experiment is higher than results of Hafiz et al. (2009) who reported $87.5 \mathrm{~kg}$ and comparatively lower than Johari and Jasmi (2009) who found 130kg in KK bulls at the same age. Ariff et al. (1993) investigated the 12-month body weight of straight bred KK and their crossbred with Hereford, Brahman and Friesian, which, were $101.1,122.6,172.3$, and $136.6 \mathrm{~kg}$, respectively, which was similar with the present finding of KK but dissimilar with the result of $\mathrm{KK} \times$ Brangus bulls. $\mathrm{KK} \times$ Brangus bulls successively showed heavier body weights than KK bulls. Surprisingly, body weight of KK was $147.4 \mathrm{~kg}$, which was insignificantly greater $(\mathrm{p}>0.05)$ than $\mathrm{KK} \times$ Brangus bulls $(146.5 \mathrm{~kg})$ at 18 months. The body weight at 18 months in KK bulls were better compared with the previous researchers of (Ismail, 1985; Hafiz et al., 2009) who reported $120.4 \mathrm{~kg}$ and $144.0 \mathrm{~kg}$ body weight, respectively, in KK within the similar age. Mean body weights were $207.5 \mathrm{~kg}$ and 230.5 $\mathrm{kg}$ for $\mathrm{KK}$ and $\mathrm{KK} \times$ Brangus bulls at 24 months of age, which were differed significantly $(p<0.05)$. These results were better as compared with previous findings of Ismaya (1987), Ariff et al. (1993) and Johari and Jasmi (2009) who observed $165 \mathrm{~kg}, 136 \mathrm{~kg}$ and $192.2 \mathrm{~kg}$, respectively, in KK bulls at 24 months of age. The difference between KK and their crosses with Brangus might be explained by the initial body weight prior to experiment as well as the birth weight of the experimental bulls.

Table 7: Multiple regression analysis for variables predicting the body weight performance of experimental bulls.

\begin{tabular}{llllll} 
Model & \multicolumn{2}{c}{$\begin{array}{c}\text { Unstandardized } \\
\text { Coefficients }\end{array}$} & $\begin{array}{c}\text { Standard } \\
\text { coefficients }\end{array}$ & t & Sig. \\
& B & Std. Error & Beta & & \\
Constant & -49.38 & 6.98 & - & -7.07 & 0.000 \\
\hline Age & 10.74 & 0.38 & 0.99 & 28.35 & 0.000 \\
ADG & 7.18 & 9.23 & 0.03 & 0.78 & 0.457 \\
\hline
\end{tabular}

Dependent variable: Body weight; $R=0.995 ; R^{2}=0.990 ;$ Sig. F $=0.000$

Puberty is the age of first breeding potential, while sexual maturity is the age of maximum breeding potential of a breeding bull (Islam et al., 2021). It was defined as the period whenever the sexual organs of a bull developed functionally for reproduction (Brito, 2014). Puberty age was defined by the ejaculation of semen following stimulation using electro-ejaculation method with at least $10 \%$ progressive motile and $50 \times 10^{6}$ sperm cell concentration (Wolf et al., 1965). Bull started to ejaculate at the age of $16^{\text {th }}$ month; however, the sperm were below the required concentration with minimum progressive motile sperm to pass the puberty. Mean differences between KK and KK $\times$ Brangus bulls for age at puberty and maturity were 5.5 and 7.3 months respectively. $\mathrm{KK} \times$ Brangus bulls did not appear to reach their puberty and maturity before 23.5 and 28.8 
months of age despite of heavier weight at puberty $(88.1 \mathrm{~kg})$ and maturity $(49.8 \mathrm{~kg})$ than KK bulls. KK bulls attained sexual maturity significantly $((\mathrm{p}<0.001)$ more than seven months earlier with significantly $(\mathrm{p}<0.01)$ lighter body weight $(185.5 \mathrm{~kg})$ than $\mathrm{KK} \times$ Brangus bulls $(235.3 \mathrm{~kg})$. There were no previous references to compare the age at puberty of KK bulls with the findings of our study. However, age at puberty of Zebu cattle bull reported almost similar results by Nogueira (2004) who stated that Brahman bull (Bos indicus) attained puberty between 16 and 17 month of age and Nelore bulls reached puberty at 18 month of age. It has been observed that different indigenous cattle bulls generally attained puberty within 14-20 months of age (Brito, 2014). Age is the most important determining factor to define the age of puberty of beef bulls for quality semen with optimum production cost (Argiris et al., 2018). In this study, body weight at puberty of KK bulls was 140.3 $\mathrm{kg}$, which is lower than the findings of Ismaya (1987) who reported it to be $151.5 \mathrm{~kg}$ at more than 16 months for same genotype. The previous researcher collected data in threemonth interval from 8-45 months of age and in different management and locations without defining the criteria of age at puberty. Moreover, the previous researcher did not report the criteria to define the age at puberty of KK bulls. The growth performance of KK bulls in our study as compared to the previous findings might be due to the effect of animal age, areas and management including feeding animals. However, $\mathrm{KK} \times$ Brangus bulls might be delayed to reach their puberty and maturity due to breed type, nutrient intake, water intake and early management stress condition prior to experiment. Similarity, KK bulls tended to attain their mature body weight at an earlier age than its counterpart. Age and body weight of all types of KK crossbred bulls at maturity were greater than straight bred KK bulls (Ariff et al., 1993). Birth weight of crossbred and purebred bulls may be one of the vital factor to differentiate the subcequenct of weight difference between the breed type. Because birth weight is first and most significant trait to be recored in the life of a bovine which directly and positively correlated with further body weight performance (Assan, 2014).

The monthly highest weight gain was obtained at 21 -month age for both genotype $0.5 \mathrm{~kg} / \mathrm{d}$ for KK and $0.8 \mathrm{~kg} / \mathrm{d}$ for $\mathrm{KK} \times$ Brangus bulls with significant difference $(p<0.05)$ between genotypes (Figure 1). There is no previous information on monthly weight gain in $\mathrm{KK}$ and $\mathrm{KK} \times$ Brangus bulls to verify our findings. However, our result was compared with the findings of indigenous breeds of other topical regions in the world. (Lestari et al., 2011) reported the weight gains of $0.6 \mathrm{~kg}$ and $0.8 \mathrm{~kg}$ in indigenous Java and Ongole crossbred bulls, respectively, under intensive feeding management in Indonesia, which is almost similar with our findings in $\mathrm{KK}$ and their crossbred bulls. These findings are also parallel in compared with the results of (Umar et al., 2007) who observed $0.5 \mathrm{~kg}$ vs. 0.6 $\mathrm{kg} / \mathrm{d}$ in Madura cattle, whereas the ADG of KK $\times$ Brangus bulls was higher than Ongole crossbred bulls ( $0.8 \mathrm{~kg}$ vs. 0.6 $\mathrm{kg} / \mathrm{d}$ ). ADG was reported $0.4 \mathrm{~kg} / \mathrm{d}$ in Bali cattle by (Klau et al., 2017) which was lower than the result in our study for KK bulls. Although, monthly ADG was significantly $(\mathrm{p}<0.05)$ higher in KK $\times$ Brangus than KK bulls at 19 and 21 months of ages but there were no significant differences $(p>0.05)$ for other ages (Figure 1). No significant difference ( $>0.05$ ) of monthly ADG obtained between KK and their crossbred bulls except 19 and 21 month of age. Mean ADG from 13 to 18 -month of age were $0.27 \pm .0$ and $0.19 \pm .0 \mathrm{~kg}$ for $\mathrm{KK}$ and $\mathrm{KK} \times$ Brangus bulls, respectively, with significant $(p<0.05)$ difference between genotype. Contrariwise, the ADGs from 13 to age at puberty were $0.35 \pm 0.1 \mathrm{~kg}$ and $0.27 \pm 0.1 \mathrm{~kg} / \mathrm{d}$ for $\mathrm{KK} \times$ Brangus bulls and KK bulls, respectively with significant $(\mathrm{p}<0.05)$ difference between groups. Islam et al. (2021) reported almost similar findings $(0.3 \mathrm{~kg} / \mathrm{d})$ through meta-data analysis of average daily gain of KK reported by different researchers in different periods. There were also no significant $(p<0.05)$ differences of ADG between $\mathrm{KK}$ and $\mathrm{KK} \times$ Brangus bulls for 19 to 24-months, 25 to 30 -months and 13 -months to age at maturity. These findings indicate that KK bulls will be able to produce similar growth performance by ensuring their required quantity and quality feeds regularly. Moreover, it was also observed that monthly ADG of both genotypes was fluctuated in different ages, which might be the effect of frequently changes of feeding pattern from Guinea grass to straw due to irregular supply of grasses associated with heavy rainfall as well as cut and carry system. Variation of nutrient contents of feeds like PKC, green fodder, straws, salt ticks and molasses along with frequent changes of feeding pattern might be attributed for the growth performance of the experimental animals in this study. Determination of accurate nutrient composition of supplied feeds and the utilization and bioavailability of those nutrients is necessary. The required amount of supplemental nutrients in balancing the diet to optimise growth and reproductive performances of bulls. On the other hand, the variations in nutrient contents of supplied feeds can be another obstacle for the variations of growth performance. On other hand, KK $\times$ Brangus bulls had significantly $(p<0.05)$ higher growth rates at 19 and 21 months of age than KK. Besides, there was no significant difference $(p<0.05)$ in average daily gain between wet and dry season for both $\mathrm{KK}$ and $\mathrm{KK} \times$ Brangus bulls during the whole year under this study. This could be due to the effect of almost similar temperature, rainfall and humidity of Malaysian tropical weather throughout the year. The results of our findings clearly shows that both local KK and their crossbred bulls have exhibited fluctuations in growth performance in different periods, which indicates the need 
of further investigations with large populations for better understanding of growth performance of KK bulls.

Growth performance of an animal is the outmost important factor for economic beef production system. Age was significantly $(\mathrm{p}<0.01)$ positive correlation with body weight in both of KK $(r=0.99)$ and $\mathrm{KK} \times$ Brangus $(\mathrm{r}$ $=0.98$ ) bulls. Age with ADG was also positive correlation but no significant relationship $(\mathrm{p}<0.05)$ in between genotypes. Moreover, age of bulls significantly $(p=0.00$, $\mathrm{t}=28.35)$ predicted the body weight performance at 0.05 level of significance by the regression model analysis. A high relationship of body weight $(\mathrm{R}=0.995)$ found with age and $\mathrm{ADG}$ ) by this study. From the findings of regression analysis, age and ADG together can be explained significantly $99.0 \%$ variance in body weight performance $\left(\mathrm{R}^{2}=0.990\right)$ which indicates age with weight gain could be determined the growth performance of bulls to be used as sires for breeding purpose. Moreover, a positive correlation of age with body weight and average daily gain significantly predicted the body weight performance, which could be helpful to determine the age of puberty and maturity of KK bulls.

\section{CONCLUSIONS AND RECOMMENDATIONS}

It can be concluded that $\mathrm{KK} \times$ Brangus bulls were better in terms of bodyweight and average daily weight gain than KK bulls. However, this study revealed that KK bulls were superior in terms of puberty and maturity as compared to $\mathrm{KK} \times$ Brangus bulls. Age had a positively significant relationship with bodyweight and average daily weight gains, which could be helpful to select bulls as sires for breeding purposes.

\section{ACKNOWLEDGEMENTS}

The authors would like to thank the Government of Bangladesh and National Agricultural Technology Project Phase 2 (NATP-2), Agricultural Research Council, Bangladesh for awarding the full funded $\mathrm{PhD}$ scholarship to first author. We would like to thank the authority of Taman Pertanian University (TPU), UPM to give their facilities to conduct the experiment at Ladang 16 .

\section{NOVELTY STATEMENT}

To the best of our knowledge, the current comparative study on growth performance and age at sexual maturity between $\mathrm{KK}$ and $\mathrm{KK} \times$ Brangus bulls conducted based on controlled experimental design is the first of its kind revealing KK's and $\mathrm{KK} \times$ Brangus bulls superior performance in achieving earlier age of sexual maturity and growth performance respectively.

\section{AUTHOR'S CONTRIBUTION}

All authors have contributed by giving their ideas, searching literature and repeated revision of the draft for preparing the manuscript.

\section{CONFLICT OF INTEREST}

The authors have declared no conflict of interest.

\section{REFERENCES}

Argiris A, Ondho YS, Santoso SI, Kurnianto E (2018). Effect of age and bulls on fresh semen quality and frozen semen production of Holstein bulls in Indonesia. In: IOP Conference Series: Earth and Environmental Science. Intstitute of Physics, pp. 1-10. https://doi. org/10.1088/1755-1315/119/1/012033

Ariff OM, Sharifah NY, Hafidz AW (2015). Status of beef industry of Malaysia. J. Anim. Sci., 18(2): 1-21.

Ariff OM, Johari JA, Dahlan I (1993). Growth pattern for body weight of straightbred and crossbred Kedah-Kelantan cattle. MARDI Res. J., 21(2): 129-134.

Assan N (2014). Genetic improvement and utilization of indigenous cattle breeds for beef production in Zimbabwe: Past, present and future prospects. A review article genetic improvement and utilization of indigenous cattle breeds for beef production. Sci. J. Agric., 1(1): 1-13.

Barth AD (2004). Pubertal development of Bos taurus beef bulls. In: In the $23^{\text {rd }}$ Proceedings of the WBC Congress, Québec, Canada , 2004. IVIS, pp. 1-5.

Brito LFC (2014). Bull development: Sexual development and puberty in bulls. In: Bovine reproduction. https://doi. org/10.1037/h0100568

Brito LFC, Barth AD, Wilde RE, Kastelic JP (2012). Effect of growth rate from 6 to 16 months of age on sexual development and reproductive function in beef bulls. Theriogenology, 77(7): 1398-1405. https://doi. org/10.1016/j.theriogenology.2011.11.003

Bureš D, Barton L (2012). Growth performance, carcass traits and meat quality of bulls and heifers slaughtered at different ages. Czech J. Anim. Sci., 57: 34-43. https://doi. org/10.17221/5482-CJAS

Clayton AD (1983). Large scale commercial cattle operation in Darabif. Proc. $7^{\text {th }}$ Ann. Malaysian Soc. Anim. Prod. Conf. Malaysian Soc. Anim. Prod. Malaysia, pp. 7-13.

Department of Veterinary Services (2020). Livestock Statistical Report/2019/2020,www.dvs.gov.my

Gamborg C, Sandøe P (2005). Sustainability in farm animal breeding: A review. Livest. Prod. Sci., https://doi. org/10.1016/j.livprodsci.2004.08.010

Hafiz MAR, Salleh SI, Raymond AK (2009). Growth performance of Kedah-Kelantan cattle in Malaysia. In: Proceedings of the $21^{\text {st }}$ Veterinary Association of Malaysia Congress. Vet. Assoc. Malaysia, pp. 204-208.

Islam MS, Yimer ND, Haron, Abd Wahid, Abdullah FFJB, Han MHWH (2021). Growth and reproductive performance of the indigenous Kedah-Kelantan (KK) Cattle: A review. Pertanika J. Trop. Agric. Sci. 44(1): 25-48. https://doi. org/10.47836/pjtas.44.1.02 
Ismail DB (1985). Growth performance, body conformation, carcass characteristics and palatability of Kedah-Kelantan cattle and it's crosses. Universiti Putra Malaysia.

Ismaya (1987). Universiti Putra Malaysia Studies in KedahKelantan, Brahman and Crossbred Bulls at Puberty and Sexual Maturity Ismaya. Universiti Putra Malaysia.

Jamaludin MH, Hassan MH, Amin MR, Zulhisyam AK (2014). The future of the Malaysian beef industry. J. Trop. Resour. Sustain. Sci., 2(1): 23-29. https://doi.org/10.47253/jtrss. v2i1.489

Johari JA, Jasmi Y (2009). Breeds and breeding program for beef production in Malaysia. In: Proceedings of the 8th Malaysia Congress on Genetics. Malays. Soc. Anim. Prod., pp. 22-28.

Klau TP, Priyono SS, Ngadiyono PN, Utomo R, Tri NC, Baliarti $\mathrm{E}$ (2017). Growth performance of male bali cattle fattening fed ration with different protein levels in smallholder farms, West Timor, Indonesia. Asian. J. Anim. Sci., 11(2): 65-73. https://doi.org/10.3923/ajas.2017.65.73

Lee WS, Khan MA, Kim HS, Kim JH, Yang SH, Ki KS, Lee HJ, Kim SB, Baek KS, Ha JK (2009). Feed consumption, growth performance and carcass evaluation of Korean Holstein bulls fed either conventional or organic diets. Anim. Prod. Sci., https://doi.org/10.1071/EA08229

Lestari CMS, Adiwinarti R, Arifin M, Purnomoadi A (2011). The performance of Java and Ongole Crossbred bull under intensive feeding management. J. Indones. Trop. Anim. Agric., https://doi.org/10.14710/jitaa.36.2.109-113

Mastura Y, Shariffah NY, Aini WN, Hanapiah AMMA, Mohd
AR, Hafiz, PC (2019). Growth performance of mafriwal dairy cattle in Malaysia. Malays. J. Vet. Res., 10(1): 43-50.

Nazli MH, Halim RA, Abdullah AM, Hussin G, Samsudin AA (2018). Potential of feeding beef cattle with whole corn crop silage and rice straw in Malaysia. Trop. Anim. Health Prod., https://doi.org/10.1007/s11250-018-1538-2

Nogueira GP (2004). Puberty in South American Bos indicus (Zebu) cattle. Anim. Reprod. Sci., 82-83(2004): 361-371. https://doi.org/10.1016/j.anireprosci.2004.04.007

Silva LHP, Paulino PVR, Assis GJF, Assis DEF, Estrada MM, Silva MC, Silva JC, Martins TS, Valadares Filho SC, Paulino MF, Chizzotti ML (2017). Effect of post-weaning growth rate on carcass traits and meat quality of Nellore cattle. Meat Sci., https://doi.org/10.1016/j.meatsci.2016.10.005

Sodiq A, Yuwono P, Sumarmono J, Wakhidati YN, Rayhan M, Sidhi AH, Maulianto A (2019). Improving production system of beef cattle agribusiness. In: IOP Conference Series: Earth and Environmental Science. https://doi. org/10.1088/1755-1315/250/1/012050

Umar M, Arifin M, Purnomoadi A (2007). Comparison study on the productivity of madura cattle with ongole crossbred cattle. In: The seminar on animal and veterinary technology. Vet. Res. Center, JIRE, Martadinata, No. 30, Bogor, Indonesia, pp. 132-136.

Wolf FR, Almoust JO, Hale EB (1965). Peripubertal behaviour and pubertal characteristics of beef bulls on high nutrient allowance. J. Anim. Sci., 24(3): 761-765. https://doi. org/10.2527/jas1965.243761x 